\title{
LICZBA CZŁONKÓW JAKO KRYTERIUM POSIADANIA UPRAWNIEŃ ZAKŁADOWEJ ORGANIZACJI ZWIAZZKOWEJ PO NOWELIZACJI USTAWY O ZWIAZZKACH ZAWODOWYCH Z 2018 ROKU
}

\begin{abstract}
The number of members as the requirement for acquiring the rights of an enterprise trade union organization after the amendment to the Trade Unions Act of the year 2018

The Constitutional Tribunal stated in June 2015 that Art. 2(1) of the Trade Unions Act, to the extent, in which it restricts rights to form and join trade unions of workers not mentioned in this Article is inconsistent with the Constitution. The Trade Unions Act was amended in July 2018 to adapt it to the new legal situation after the judgement of the Constitutional Tribunal. Among the amended provisions were those of Art. $25^{1}$ regulating the conditions conferring the rights of an enterprise trade union organization on a trade union organization. The subject of the present study is comparing the previous and new regulations of the aforementioned Article and assessing changes introduced in this scope, as well as establishing, whether the amendments are sufficient in the context of a significant number of micro employers operating in the labour market.
\end{abstract}

Słowa kluczowe: warunki posiadania przez organizację związkową uprawnień zakładowej organizacji związkowej, osoby wykonujące pracę zarobkową, mikropracodawcy, międzyzakładowe organizacje związkowe, nowelizacja ustawy o związkach zawodowych z $2018 \mathrm{r}$.

Keywords: conditions conferring the rights of an enterprise trade union organization on a trade union organization, salaried workers, micro employers, inter-enterprise trade union organizations, the amendment to the Trade Unions Act of the year 2018

ASJC: 3308, JEL: K31

\section{Uwagi wstępne}

Ustawa z dn. 23 maja 1991 r. o związkach zawodowych (Dz.U. 2019, poz. 263 tekst jedn., dalej: „ustawa związkowa”, „u.z.z.”) zawiera od 2003 r. art. $25^{1}$ przewidujący wymogi, jakie powinna spełniać organizacja związkowa, aby posiadała uprawnienia 
zakładowej organizacji związkowej. Zgodnie z dotychczasową treścią przepisów tego artykułu uprawnienia zakładowej organizacji związkowej przysługiwały organizacji zrzeszającej co najmniej 10 członków będących albo pracownikami lub osobami wykonującymi pracę na podstawie umowy o pracę nakładczą u pracodawcy objętego działaniem tej organizacji, albo funkcjonariuszami wymienionymi w art. 2 ust. 6 ustawy, pełniącymi służbę w jednostce objętej działaniem tej organizacji, przy czym wskazana organizacja była obowiązana przedstawiać co kwartał pracodawcy albo dowódcy jednostki informację o łącznej liczbie członków, w tym o liczbie członków będących pracownikami, wykonawcami lub funkcjonariuszami (por. art. 3 pkt 1 ustawy z dn. 26 lipca 2002 r. o zmianie ustawy - Kodeks pracy oraz o zmianie niektórych innych ustaw, Dz.U. 2002, nr 135, poz. 1146).

Doktryna prawa pracy od początku niezupełnie jednolicie oceniała przywołane przepisy. Z jednej strony zwracała uwagę na korzyści wynikające $\mathrm{z}$ wprowadzonych regulacji, takie jak pozbawienie możliwości działania organizacji związkowych zrzeszających zbyt małą liczbę członków i istniejących głównie dla zapewnienia ochrony działaczom związkowym (Dubowik 2003, s. 23) czy przeciwdziałanie rozdrobnieniu ruchu związkowego u dużych pracodawców (Szmit 2013, s. 385). Z drugiej strony jednak dostrzegała negatywne skutki wskazanych unormowań - między innymi ograniczenie wolności zrzeszania się na szczeblu zakładowym (Dubowik 2003, s. 21; Szmit 2013, s. 385) oraz znaczne utrudnienie działania związków zawodowych u małych pracodawców i w konsekwencji wykluczenie zatrudnionych u nich pracowników z zakresu oddziaływania zbiorowego prawa pracy (Rutkowska 2016, s. 228 i n.). Podkreślała także mankamenty tych przepisów z punktu widzenia legislacyjnej poprawności - przede wszystkim pozostawienie istotnych kwestii poza zakresem regulacji i wynikające z tego spory interpretacyjne wpływające negatywnie na praktykę dokonywania ustaleń co do posiadania przez organizacje związkowe uprawnień zakładowej organizacji związkowej (Płażek, Sobczyk 2003, s. 23; Dubowik 2006, s. 19; Baran 2010, s. 236). Pomimo tego wskazane przepisy obowiązywały bez jakichkolwiek zmian przez kilkanaście lat. W czerwcu 2015 r. Trybunał Konstytucyjny (K 1/13, OTK-A 2015, nr 6, poz. 80) uznał jednak, że art. 2 ust. 1 u.z.z. w części, w jakiej ogranicza wolność tworzenia i wstępowania do związków zawodowych osobom wykonującym pracę zarobkową niewymienionym $\mathrm{w}$ tym przepisie, jest niezgodny z art. 59 ust. $1 \mathrm{w}$ zw. $\mathrm{z}$ art. 12 Konstytucji (Dz.U. 1997, nr 78, poz. 483 ze zm., dalej: „Konstytucja”) ${ }^{1}$. W celu dostosowania regulacji prawnych dotyczących funkcjonowania organizacji związkowych do nowej sytuacji prawnej (por. uzasadnienie projektu ustawy o zmianie ustawy o związkach zawodowych oraz niektórych innych ustaw zgłoszonego przez Radę Ministrów w dn. 12 października 2017 r., druk nr 1933, s. 61, dalej: „uzasadnienie projektu”) ustawodawca w lipcu 2018 r. znowelizował ustawę (por. ustawa z dn. 5 lipca 2018 r. o zmianie ustawy o związkach zawodowych oraz niektórych innych ustaw, Dz.U. 2018, poz. 1608, dalej: „,ustawa nowelizacyjna”, „ustawa

${ }^{1}$ W wyroku tym także art. 2 ust. 2 u.z.z. oceniono jako niezgodny z art. 59 ust. 1 w zw. z art. 12 Konstytucji. 
nowelizacyjna z lipca 2018 r.”; weszła w życie w dn. 1 stycznia 2019 r.), nadając nową treść także przepisom art. 251․ Warto porównać dotychczasowe regulacje wskazanego artykułu z nowymi, poddać wstępnej ocenie wprowadzone zmiany, a także ustalić, czy zmiany te są wystarczające w kontekście działania na rynku pracy znacznej liczby mikropracodawców. Temu właśnie poświęcone jest niniejsze opracowanie.

\section{Krąg członków uwzględnianych przy ustalaniu, czy organizacja posiada uprawnienia zakładowej organizacji związkowej}

Jedna z ważniejszych zmian, jakie zostały wprowadzone do art. $25^{1}$ ustawą nowelizacyjną, dotyczy rozszerzenia kręgu członków uwzględnianych przy ustalaniu, czy danej organizacji przysługują uprawnienia zakładowej organizacji związkowej. Do tej pory brano pod uwagę pracowników, wykonawców pracy nakładczej i funkcjonariuszy wymienionych w art. 2 ust. 6 u.z.z. Obecnie z ustawy wynika, że posiadanie uprawnień zakładowej organizacji związkowej determinuje liczba członków organizacji będących pracownikami lub innymi niż pracownicy osobami wykonującymi pracę zarobkową. Wprowadzony do ustawy słowniczek pojęć wyjaśnia w art. $1^{1}$ pkt 1 , że innymi niż pracownicy osobami wykonującymi pracę zarobkową są osoby świadczące pracę za wynagrodzeniem na innej podstawie niż stosunek pracy, jeżeli spełniają one dodatkowo dwa warunki: nie zatrudniają do tego rodzaju pracy innych osób (niezależnie od podstawy zatrudnienia) oraz mają takie prawa i interesy związane z wykonywaniem pracy, które mogą być reprezentowane i bronione przez związek zawodowy². Jak widać, chodzi tu więc o osoby świadczące osobiście pracę określonego rodzaju za wynagrodzeniem na innej podstawie niż stosunek pracy oraz posiadające prawa i interesy związane $\mathrm{z}$ wykonywaniem pracy, które mogą być reprezentowane i bronione przez związek zawodowy (w praktyce pojawiają się niekiedy problemy z oceną spełnienia przez określone osoby wskazanych przesłanek; por. Baran 2018, s. 71 i n.; Florek 2018, s. 55 i n.).

Ustalając, czy dana organizacja ma uprawnienia zakładowej organizacji związkowej, bierze się dodatkowo pod uwagę staż pracy osób wykonujących pracę zarobkową niebędących pracownikami. Zgodnie bowiem z art. $25^{1}$ ust. 1 pkt 2 u.z.z. osoby te są uwzględniane tylko wtedy, gdy świadczą pracę na rzecz pracodawcy objętego działaniem organizacji przez co najmniej 6 miesięcy ${ }^{3}$. Jak wskazano w uzasadnieniu

2 W związku z tym, że ustawa nowelizacyjna przewiduje, iż prawo tworzenia i wstępowania do związków zawodowych przysługuje również osobom wykonującym pracę zarobkową niebędącym pracownikami, szerzej ujmuje też pojęcie pracodawcy. Obejmuje ona tym pojęciem nie tylko pracodawcę w rozumieniu art. 3 ustawy z dn. 26 czerwca 1974 r. - Kodeks pracy (Dz.U. 2019, poz. 1040 tekst jedn. ze zm., dalej: „Kodeks pracy”, „k.p.”), ale także jednostkę organizacyjną, choćby nie posiadała osobowości prawnej, oraz osobę fizyczną, jeżeli zatrudniają one inną niż pracownik osobę wykonującą pracę zarobkową, niezależnie od podstawy tego zatrudnienia (art. $1^{1}$ pkt 2 u.z.z.).

3 Brak analogicznego wymogu wobec pracowników uzasadnia się trwałością stosunku pracy wynikającą przede wszystkim z ciągłości świadczenia pracy. Inaczej bowiem niż w przypadku chociażby 
projektu nowelizacji (s. 27), celem przyjęcia powyższego wymogu jest umożliwienie korzystania z ustawowych uprawnień zakładowej organizacji związkowej jedynie organizacjom zrzeszającym osoby wykonujące pracę zarobkową, które pozostają w trwałej więzi z pracodawcą. Co ciekawe jednak, okres zatrudnienia nie jest istotny dla posiadania prawa koalicji związkowej. Okazuje się więc, że niektóre osoby świadczące pracę zarobkową mają pełne prawo koalicji, czyli mogą tworzyć lub przystępować do organizacji związkowych i być przez nie reprezentowane oraz bronione, ale nie są brane pod uwagę przy ustalaniu, czy organizacjom tym przysługują uprawnienia zakładowej organizacji związkowej ${ }^{4}$. Podobnie jest zresztą w przypadku osób z ograniczonym prawem koalicji - nie tylko bezrobotnych, emerytów czy rencistów, którzy od dawna posiadają prawo przynależności i wstępowania do związków zawodowych, ale także osób wykonujących osobiście pracę bez wynagrodzenia (np. wolontariuszy i stażystów), którym dopiero ustawa nowelizacyjna przyznała to prawo.

W literaturze przedmiotu podkreśla się, że nieuwzględnianie niektórych związkowców przy ustalaniu, czy organizacji związkowej przysługują uprawnienia zakładowej organizacji związkowej, oznacza marginalizację roli tych członków w płaszczyźnie kompetencyjnej i w konsekwencji ich dyskryminację funkcjonalną, „,co budzi poważne wątpliwości w świetle postanowień art. 59 ust. 1 Konstytucji RP, który to przepis nie różnicuje statusu osób zrzeszonych w związkach zawodowych" (Baran 2010, s. 234). Nie bez znaczenia dla oceny omawianego rozwiązania wydaje się też to, że nieuwzględnianie części związkowców prowadzi niekiedy do paradoksalnej sytuacji polegającej na tym, iż dana organizacja zrzesza wystarczającą liczbę członków, żeby uczestniczyć w obrocie prawnym jako osoba prawna, ale ma wśród nich zbyt mało osób wykonujących pracę zarobkową (pracowników i niepracowników spełniających wspomniane wyżej przesłanki), aby móc reprezentować i bronić praw, interesów zawodowych i socjalnych ludzi pracy, choć z definicji jest do tego powołana (szerzej o takiej organizacji: Dubowik 2006, s. 22-23).

Niezależnie od wskazanych zastrzeżeń, uwzględnianie w szerszym zakresie niż dotychczas osób wykonujących pracę zarobkową niebędących pracownikami ułatwia organizacjom związkowym - przynajmniej teoretycznie - spełnianie wymogów warunkujących posiadanie uprawnień związkowych. Zakłada się, że na skutek rozszerzenia prawa koalicji związkowej dojdzie do wzrostu uzwiązkowienia u pracodawców. Ponieważ może to zwiększyć ryzyko sztucznego zawyżania liczebności organizacji związkowych i co za tym idzie - zbytniego obciążania pracodawców kosztami związanymi z ochroną i ułatwieniami dla działaczy związkowych, za celowe uznano przyjęcie rozwiązania mającego służyć zachowaniu równowagi w zbiorowych stosunkach pracy

niektórych zleceniobiorców czy osób samozatrudnionych świadczenie pracy przez pracowników nie sprowadza się do jednorazowego wykonania jakiejś czynności lub zespołu czynności składającego się na określony rezultat, lecz polega na podejmowaniu pewnych działań w sposób powtarzający się, podczas istnienia trwałej więzi prawnej z pracodawcą (uzasadnienie projektu, s. 27).

${ }^{4}$ Warto $\mathrm{w}$ tym kontekście zauważyć, że w literaturze przedmiotu postuluje się uzależnienie prawa koalicji niepracowników od spełnienia przez nich wymogu co najmniej sześciomiesięcznego okresu zatrudnienia u danego pracodawcy (Baran 2018, s. 72-73). 
(uzasadnienie projektu, s. 29). Do art. $25^{1}$ u.z.z. został wprowadzony ust. 5, który na wzór nieobowiązującego już art. $241^{25 a} \$ 3$ k.p. przewiduje, że jeżeli wykonujący pracę zarobkową (zarówno pracownik, jak i niepracownik) należy do więcej niż jednej zakładowej organizacji związkowej u danego pracodawcy, może być uwzględniony przy ustalaniu liczby członków zrzeszonych w organizacji tylko jako członek jednej wskazanej przez siebie zakładowej organizacji związkowej.

\section{Obowiązek informacyjny zakładowej organizacji związkowej}

Każda zakładowa organizacja związkowa ma obowiązek informować o liczbie swoich członków. Obowiązek ten przewidywał i przewiduje art. $25^{1}$ ust. 2 u.z.z. Zgodnie z brzmieniem tego przepisu sprzed nowelizacji organizacja przedstawiała co kwartał - według stanu na ostatni dzień kwartału - w terminie do 10. dnia miesiąca następującego po tym kwartale pracodawcy lub dowódcy jednostki objętego jej działaniem informację o łącznej liczbie członków tej organizacji, w tym o liczbie członków będących pracownikami, osobami wykonującymi pracę na podstawie umowy o pracę nakładczą lub funkcjonariuszami posiadającymi prawo koalicji.

Ustawa nowelizacyjna z lipca 2018 r. wprowadziła zmiany polegające na ograniczeniu i doprecyzowaniu powyższego obowiązku. Ograniczenie odnosi się do dwóch aspektów. Po pierwsze informacja przekazywana pracodawcy ma dotyczyć wyłącznie liczby związkowców będących pracownikami lub innymi niż pracownicy osobami wykonującymi pracę zarobkową, a nie - jak dotychczas - także ogólnej liczby członków organizacji. Po drugie przewiduje się zmniejszenie częstotliwości informowania. O ile dotychczas organizacja związkowa była zobowiązana do podawania swojego stanu liczbowego czterokrotnie w ciągu roku, o tyle po nowelizacji ma to czynić tylko dwukrotnie - do 10 stycznia i do 10 lipca, według stanu na dzień 30 czerwca i 31 grudnia. Wydaje się, że wymóg aktualizowania co pół roku informacji o liczbie członków organizacji związkowej jest wystarczający. Istotne jest przy tym, że dostrzegając potrzebę większej kompleksowości regulacji, do ustawy związkowej wprowadzono przepis, zgodnie z którym zmiany stanu liczbowego następujące w ciągu sześciomiesięcznego okresu sprawozdawczego pozostają bez wpływu na uprawnienia zakładowej organizacji związkowej (art. $25^{1}$ ust. 11). Do tej pory podobne stanowisko zajmowano w judykaturze ${ }^{5}$, natomiast kwestia ta nie była wprost unormowana w ustawie.

Nową regulację stanowi również przepis art. $25^{1}$ ust. 3, z którego wynika, że jeżeli w trakcie sześciomiesięcznego okresu sprawozdawczego zostaje utworzona zakładowa

${ }^{5}$ Por. np. wyrok SN z 19 sierpnia 2015 r., II PK 208/14, LEX nr 1802577, w którym Sąd Najwyższy stwierdził, że „zmniejszenie liczby członków zakładowej organizacji związkowej poniżej 10 osób nie powoduje natychmiastowej utraty jej uprawnień [...] a organizacja taka zachowuje przysługujące jej uprawnienia do końca kwartału, na początku którego zgłoszona pracodawcy liczba jej członków wynosiła co najmniej 10 osób". 
organizacja związkowa, przedstawia ona pracodawcy pierwszą informację o liczbie członków - według stanu na dzień złożenia informacji - w terminie 2 miesięcy od dnia utworzenia organizacji ${ }^{6}$. Wywiązanie się z tego obowiązku nie wyłącza konieczności złożenia przez nową organizację informacji o stanie liczbowym do 10 stycznia i do 10 lipca.

Na szczególne podkreślenie zasługuje uzupełnienie art. $25^{1}$ u.z.z. o przepisy przewidujące możliwość weryfikacji informacji przekazywanej przez zakładową organizację związkową o liczbie jej członków. Brak regulacji w tym przedmiocie był od początku postrzegany jako istotny mankament art. $25^{1} \mathrm{w}$ dotychczasowym brzmieniu (Dubowik 2003, s. 22; 2006, s. 19; Baran 2010, s. 236). Poszukując rozwiązań niwelujących ten brak, w nauce prawa pracy zwracano uwagę na możliwość badania przez sąd pracy liczebności organizacji związkowej przy okazji rozpoznawania innych spraw (np. odnoszących się do ochrony trwałości zatrudnienia pracowników; por. Dubowik 2006, s. 19), a także uznawano za dopuszczalne występowanie z powództwem o ustalenie nieposiadania przez daną organizację uprawnień zakładowej organizacji związkowej na podstawie art. 189 ustawy z dn. 17 listopada 1964 r. - Kodeks postępowania cywilnego (Dz.U. 2018, poz. 1360 tekst jedn. ze zm.; Baran 2010, s. 236-237; Płażek, Sobczyk 2013, s. 24). Jednocześnie dostrzegano jednak słabe strony tych rozwiązań. Jeżeli chodzi o pierwsze z nich, miało ono ograniczony zakres odniesienia ze względu na uzależnienie badania liczebności organizacji związkowej od rozpoznawania przez sąd sprawy, w której spełnienie przez organizację wymogu z art. $25^{1}$ ust. 1 u.z.z. było istotne dla jej rozstrzygnięcia. Zastrzeżenia zaś co do drugiego rozwiązania dotyczyły zwłaszcza postępowania dowodowego, w ramach którego to na pracodawcy spoczywał ciężar udowodnienia, że liczba członków organizacji związkowej wynosiła na koniec kwartału mniej niż 10 związkowców o wymaganym statusie (Płażek, Sobczyk 2013, s. 24; wyrok SN z 19 sierpnia 2015 r., II PK 208/14, LEX nr 1802577). Problem polegał na tym, że pracodawca na ogół nie był w stanie tego udowodnić. Oba rozwiązania budziły także wątpliwości w związku z przewlekłością postępowań sądowych.

Wobec powyższego konieczne było znalezienie i wyraźne uregulowanie nowego rozwiązania, które stworzyłoby możliwość bardziej skutecznego weryfikowania informacji organizacji związkowej o liczbie jej członków. W tym kontekście na uwagę zasługują wprowadzone nowelizacją przepisy art. $25^{1}$ ust. $7-10$ i 12 u.z.z. Wynika z nich między innymi, że pracodawca lub działająca u niego organizacja związkowa może zgłosić pisemne zastrzeżenie co do liczebności danej zakładowej organizacji związkowej w terminie 30 dni od dnia przedstawienia przez tę organizację informacji, a wówczas organizacja, wobec której zgłoszono zastrzeżenie, występuje w terminie 30 dni do sądu rejonowego - sądu pracy właściwego ze względu na siedzibę pracodawcy - z wnioskiem o ustalenie liczby

${ }^{6}$ Brak takiego obowiązku informacyjnego przed nowelizacją znajdował potwierdzenie $\mathrm{w}$ orzecznictwie, np. w wyroku SN z 2 marca 2012 r., I PK 120/11, LEX nr 1271581. Sąd Najwyższy wskazał, że przepisy ustawy o związkach zawodowych nie zobowiązują zakładowej organizacji związkowej do informowania pracodawcy o liczbie jej członków w okresie między dniem powstania tej organizacji a końcem kwartału, w którym powstała. 
członków na ostatni dzień danego półrocza (zakładowa organizacja związkowa może wystąpić z wnioskiem o ustalenie liczby członków również z własnej inicjatywy).

Złożenie na czas wskazanego wniosku ma istotne znaczenie. W przypadku bowiem gdy organizacja związkowa nie wystąpi do sądu, zgodnie z art. $25^{1}$ ust. 9 u.z.z. przestają jej przysługiwać uprawnienia zakładowej organizacji związkowej do czasu wykonania tego obowiązku. Jeżeli jednak organizacja, wobec której zgłoszono zastrzeżenie, złoży we właściwym terminie wniosek do sądu pracy, wówczas może zostać pozbawiona uprawnień związkowych dopiero na skutek wydania przez sąd orzeczenia ustalającego liczbę jej członków na poziomie niższym niż 10 osób wykonujących pracę zarobkową.

Rozwiązanie to należy uznać za jak najbardziej właściwe. Na pozytywną ocenę zasługuje w szczególności to, że utratę uprawnień związkowych pociąga za sobą dopiero niewystąpienie przez organizację związkową do sądu z wnioskiem o ustalenie liczby jej członków, a nie samo zgłoszenie wobec niej zastrzeżenia. W przypadku zakwestionowania liczebności danej organizacji związkowej należy dać jej możliwość wykazania, że zrzesza co najmniej 10 członków o odpowiednim statusie, zanim pozbawi się ją uprawnień związkowych. Przyjęcie odmiennego rozwiązania zachęcałoby pracodawcę i inne organizacje związkowe do zgłaszania nieuzasadnionych zastrzeżeń.

W kontekście ostatniej z poczynionych uwag warto zauważyć, że w związku z ryzykiem nadużyć $\mathrm{w}$ ustawie nowelizacyjnej przewiduje się ograniczenie częstotliwości stosowania mechanizmu weryfikacji - jeżeli zastrzeżenie co do liczebności danej zakładowej organizacji związkowej okazało się bezpodstawne, może ono zostać ponownie zgłoszone przez pracodawcę lub inną zakładową organizację związkową nie wcześniej niż po upływie roku od dnia uprawomocnienia się orzeczenia w sprawie ustalenia liczby członków organizacji.

Przedstawiony mechanizm weryfikacji, wzorowany na nieobowiązujących już przepisach art. $241^{25 a} \$ \$ 4$ i 5 k.p., dotyczących stwierdzania reprezentatywności organizacji związkowej uczestniczącej w rokowaniach nad zawarciem układu zbiorowego pracy, zdaje się potwierdzać stale rosnące znaczenie sądu pracy w rozstrzyganiu sporów z zakresu zbiorowego prawa pracy (Sanetra 2012, s. 113 i n.). Wydaje się, że poddanie kontroli sądu informacji organizacji związkowej o liczbie jej członków zasługuje na aprobatę. W praktyce jednak pewnym utrudnieniem może być wspomniana już wyżej przewlekłość postępowań sądowych. Problem ten został także dostrzeżony w ustawie nowelizacyjnej. Przyjęto w niej sześćdziesięciodniowy termin na wydanie przez sąd orzeczenia w sprawie ustalenia liczby członków organizacji związkowej. Ma to „zapobiec przedłużaniu stanu niepewności co do tego, czy pracodawca ma obowiązek współdziałać z organizacją związkową i respektować przysługujące jej uprawnienia zakładowej organizacji związkowej" (uzasadnienie projektu, s. 31). Otwarte pozostaje pytanie, czy wyznaczenie wskazanego terminu rzeczywiście wystarczy, aby osiągnąć ten cel.

Przepisy regulujące obowiązek informacyjny zakładowej organizacji związkowej zostały uzupełnione przez ustawę nowelizacyjną również w zakresie skutków niedopełnienia tego obowiązku. Na tle wcześniej obowiązującego art. $25^{1}$ u.z.z. prezentowane były w tym przedmiocie różne poglądy. Z jednej strony stwierdzano, że „organizacja, która 
nie realizuje cokwartalnej sprawozdawczości, nie traci ex lege ustawowych uprawnień, ponieważ z normatywnego punktu widzenia decydujące znaczenie ma istniejąca obiektywnie liczba członków, a nie informacja o niej" (Baran 2010, s. 236; por. Pudełko 2013, s. 368 i n.; Świątkowski 2013, s. 607 i n.; wyrok SA w Katowicach z 29 grudnia 2015 r., III APa 41/15, LEX nr 1997497). Z drugiej strony jednak zauważano, iż nieprzedstawienie przez zakładową organizację związkową informacji wymaganej na podstawie art. $25^{1}$ ust. 2 powoduje, że nie są wadliwe czynności podjęte przez pracodawcę bez wymaganego współdziałania $\mathrm{z}$ tą organizacją aż do dnia przedstawienia tej informacji (Baran 2010, s. 237; Płażek, Sobczyk 2013, s. 23-24; uchwała SN z 20 grudnia 2012 r., III PZP 7/12, LEX nr 1274988; wyrok SN z 6 października 2011 r., III PK 17/11, LEX nr 1227510; wyrok SN z 20 czerwca 2017 r., I PK 198/16, LEX nr 2342186). Pod wpływem tego ostatniego stanowiska w ustawie nowelizacyjnej wprost wskazano, że organizacja, która nie wypełniła w terminie obowiązku informacyjnego, nie ma uprawnień zakładowej organizacji związkowej do czasu wykonania tego obowiązku. Wyraźne określenie skutku niewywiązania się z obowiązku informacyjnego należy ocenić jak najbardziej pozytywnie, przede wszystkim z tego względu, że rozwiewa to dotychczasowe wątpliwości i co za tym idzie - sprzyja pewności prawa.

\section{Problem liczby członków jako kryterium posiadania uprawnień zakładowej organizacji związkowej u mikropracodawców ${ }^{7}$}

Jak widać na podstawie dotychczasowych rozważań, ustawa nowelizacyjna z lipca $2018 \mathrm{r}$. rozszerzyła krąg związkowców uwzględnianych przy ustalaniu, czy danej organizacji przysługują uprawnienia zakładowej organizacji związkowej, a także zmodyfikowała i znacząco uzupełniła przepisy dotyczące obowiązku informacyjnego wskazanej organizacji. Niezależnie jednak od wprowadzonych zmian i uzupełnień, wymagania przewidziane $\mathrm{w}$ art. $25^{1}$ u.z.z. pozostają co do istoty takie same. W dalszym ciągu konieczne jest zrzeszanie przez organizację związkową co najmniej 10 członków o określonym statusie, aby przysługiwały jej uprawnienia zakładowej organizacji związkowej. Oznacza to, że u pracodawców zatrudniających do 9 osób nadal nie mogą działać zakładowe organizacje związkowe. Istotne jest przy tym, że ustawa nowelizacyjna nie przewiduje żadnej nowej formuły obecności związków zawodowych u takich pracodawców. Ustawodawca zdaje się więc cały czas przyjmować, iż wystarczającą alternatywą dla zakładowych organizacji związkowych są międzyzakładowe organizacje związkowe ${ }^{8}$. Warto zauważyć, że organizacje te wprowadzono do polskiego prawa pracy właśnie po to, aby pracownicy zakładów pracy, w których stan zatrudnienia uniemożliwia utworzenie zakładowej

\footnotetext{
7 W niniejszym opracowaniu za mikropracodawcę uznaje się pracodawcę zatrudniającego do 9 osób.

${ }^{8}$ Podobnie przyjął Trybunał Konstytucyjny w wyroku z września 2006 r. (K 45/04, OTK-A 2006, nr 8, poz. 111), uznając międzyzakładowe organizacje związkowe za remedium na brak możliwości działania zakładowych organizacji związkowych u najmniejszych pracodawców.
} 
organizacji związkowej, mogli utworzyć wspólną organizację związkową o charakterze międzyzakładowym ${ }^{9}$.

Problem polega jednak na tym, że cel ten nie jest realizowany w praktyce. Międzyzakładowe organizacje związkowe ułatwiają wprawdzie zrzeszanie się pracownikom, „których łączy silne poczucie wspólnoty interesów - wynikające albo z utrwalonego poczucia solidarności zawodowej (np. oświata, służba zdrowia), albo z faktu powiązań (organizacyjnych, kapitałowych) między pracodawcami” (Latos-Miłkowska 2012, s. 123), niemniej jednak w innych przypadkach na ogół nie działają, co wynika z tego, że konstrukcja prawna tych organizacji jest z założenia wadliwa. Jak słusznie podkreśla się w literaturze przedmiotu, poważne zastrzeżenia budzi „przeniesienie wzorca zakładowej organizacji związkowej na większą liczbę zakładów pracy należących do różnych pracodawców” i co za tym idzie - możliwość reprezentowania pracowników danego pracodawcy przez działaczy związkowych zatrudnionych u innych, niekiedy konkurencyjnych pracodawców (Hajn 2012, s. 47), a także to, że „międzyzakładowe organizacje związkowe nie odpowiadają specyfice zbiorowych stosunków pracy”, ponieważ w przeciwieństwie do zakładowych organizacji związkowych nie są „nierozerwalnie związane z daną załogą i danym pracodawcą określoną więzią prawną i w dużej mierze wspólnym interesem" (Piątkowski 2014, s. 79).

Okazuje się więc, że zakładowe organizacje związkowe nie mogą działać u najmniejszych pracodawców, międzyzakładowe organizacje związkowe stanowiące dla nich jedyną alternatywę w praktyce nie działają (ze względu na wadliwość ich konstrukcji prawnej), a ustawodawca nadal nie dostrzega potrzeby wprowadzenia jakichkolwiek zmian prawnych zmierzających do tego, aby u mikropracodawców rzeczywiście mogły być obecne związki zawodowe. W konsekwencji u wskazanych pracodawców nie ma organizacji związkowych.

Można się zastanawiać, czy brak aktywności ze strony ustawodawcy nie jest tutaj świadomym zabiegiem mającym na celu utrzymanie zróżnicowania sytuacji mikropracodawców i pozostałych pracodawców w zakresie dotyczącym obecności u nich organizacji związkowych. Jak każda dyferencjacja pracodawców, także ta odnosząca się do działania u nich związków zawodowych stanowi niezwykle złożone zagadnienie. Z jednej strony jest oczywiste, że istnieje potrzeba odmiennego ukształtowania - przynajmniej w pewnym zakresie - sytuacji prawnej najmniejszych pracodawców. Należy bowiem mieć na uwadze to, że takim pracodawcom wyjątkowo trudno jest zabezpieczyć swoje interesy na wypadek zakłóceń procesu świadczenia pracy: mają oni mniejsze możliwości finansowe (związane chociażby z ograniczonym dostępem do kredytów), posiadają mniejszą zdolność do ponoszenia kosztów wynikających z prowadzonej działalności itp. (Goździewicz 2013, s. 23 i n.; Latos-Miłkowska 2013, s. 345 i n.). W tym kontekście nieobecność organizacji związkowych u najmniejszych pracodawców oznacza możliwość

9 Por. art. 1 pkt 6 ustawy z dn. 24 lipca 1985 r. o zmianie ustawy o związkach zawodowych i niektórych innych ustaw określających uprawnienia związków zawodowych (Dz.U. 1985, nr 35, poz. 162). 
sprawniejszego zarządzania zakładami pracy, większą swobodę w zakresie podejmowania decyzji i brak obciążenia dodatkowymi kosztami związanymi z działalnością związkową.

Z drugiej strony jednak odmienne traktowanie mikropracodawców w zakresie dotyczącym obecności u nich organizacji związkowych może budzić zastrzeżenia. Związki zawodowe są nadal najważniejszym podmiotem reprezentującym zatrudnionych w bardzo wielu różnych obszarach (w niektórych na zasadzie wyłączności). Brak skutecznego zapewnienia możliwości działania tych organizacji u najmniejszych pracodawców jest równoznaczny z tym, że nie funkcjonuje u nich zdecydowana większość instytucji zbiorowego prawa pracy. Na uwagę zasługuje zwłaszcza brak dialogu społecznego, pomimo tego, że zarówno standardy międzynarodowe, jak i Konstytucja oraz Kodeks pracy nadają jemu i jego efektom w postaci autonomicznych źródeł prawa pracy szczególne znaczenie.

Co istotne, ograniczenie zakresu działania najważniejszych instytucji zbiorowego prawa pracy ma daleko idące skutki także w płaszczyźnie indywidualnego prawa pracy (Zieliński 2000, s. 15-16). Zatrudnieni bowiem, nie mogąc liczyć na reprezentowanie i obronę przez organizacje związkowe, muszą występować w relacjach z mikropracodawcą samodzielnie. W związku jednak z tym, że ich pozycja jest znacznie słabsza niż podmiotów o charakterze zbiorowym, istnieje poważne niebezpieczeństwo zachwiania równowagi w stosunkach zatrudnienia na korzyść pracodawcy, a tym samym istotnego osłabienia ochrony praw i interesów zatrudnionych. Ryzyko to dotyczy sporej liczby osób. Potwierdzają to chociażby dane odnoszące się do mikroprzedsiębiorstw: w $2016 \mathrm{r}$. w przedsiębiorstwach tych pracowało ok. 3862 tys. osób, w tym 1374 tys. zatrudnionych (Raport... 2018, s. 21-22).

Negatywne skutki nieobecności organizacji związkowych u najmniejszych pracodawców skłaniają doktrynę prawa pracy do zgłaszania różnych propozycji zmian, jakie jej zdaniem ustawodawca powinien wprowadzić w prawie związkowym. Nie wdając się w szczegóły - zagadnienie to wykracza bowiem poza zakres niniejszego artykułu warto zwrócić uwagę na trzy postulaty. Pierwszą propozycję stanowi obniżenie, a nawet zniesienie wymogu zrzeszania minimalnej liczby 10 członków jako kryterium posiadania przez organizację związkową uprawnień zakładowej organizacji związkowej (Szmit 2013, s. 385; Piątkowski 2014, s. 86 i n.). Z jednej strony dokonanie takiej zmiany byłoby stosunkowo łatwe i pozwoliłoby na złagodzenie lub usunięcie ograniczenia autonomii związkowej na szczeblu zakładowym. Z drugiej jednak strony realizacja tego postulatu oznaczałaby podważenie racji, które legły u podstaw wprowadzenia art. $25^{1}$ do ustawy związkowej (Szmit 2013, s. 385), a także utrwalenie koncepcji zakładowej organizacji związkowej jako jedynej formy organizacyjnej związków zawodowych posiadającej możliwości działania na szczeblu zakładowym.

$\mathrm{W}$ innym kierunku zmierza druga ze zgłaszanych propozycji rozwiązania problemu nieobecności związków zawodowych u mikropracodawców. Rozważa się mianowicie dopuszczenie działania na szczeblu zakładowym również innych form organizacyjnych związków zawodowych niż zakładowe organizacje związkowe (Hajn 2012, s. 50 i n.; Stelina 2013, s. 165-166; Szmit 2018, s. 187 i n.). Szczególnie dużym zainteresowaniem 
cieszy się koncepcja delegatów związkowych. Można się zastanawiać, czy wprowadzenie tej koncepcji w życie na tyle skutecznie zmieniłoby obecny model ruchu związkowego, że funkcjonowałby on o wiele lepiej u najmniejszych pracodawców. Wydaje się, że w dużej mierze zależałoby to od nastawienia samych organizacji związkowych do instytucji delegatów.

Najbardziej radykalny jest trzeci postulat, który sprowadza się do wyprowadzenia związków zawodowych z zakładów pracy. Za takim rozwiązaniem przytacza się wiele argumentów (Florek 2012, s. 205 i n.), ale brakuje obecnie rzeczywistej woli dokonania tak radykalnej zmiany. Gdyby jednak zdecydowano się na to w przyszłości, oznaczałoby to całkowite przeobrażenie modelu związków zawodowych w Polsce.

Mając na względzie to wszystko, na co zwrócono uwagę wyżej, uzasadniona wydaje się konkluzja, że zmiany i uzupełnienia wprowadzone do art. $25^{1}$ ustawą nowelizacyjną nie są wystarczające. Zachowanie istoty omawianej regulacji (uzależnienie posiadania uprawnień związkowych od zrzeszania przez daną organizację co najmniej 10 członków o określonym statusie) w połączeniu ze skromną praktyką tworzenia międzyzakładowych organizacji związkowych stanowiących jedyną alternatywę dla zakładowych organizacji związkowych sprawia, że u mikropracodawców na ogół nie działają związki zawodowe, a to $\mathrm{z}$ kolei powoduje niekorzystne konsekwencje prawne dla zatrudnionych. Stworzenie właściwych ram prawnych do działania związków zawodowych u najmniejszych pracodawców z pewnością nie jest proste, nie usprawiedliwia to jednak bierności ustawodawcy, który inspirując się propozycjami zgłaszanymi w tym zakresie w nauce prawa pracy, powinien mimo wszystko podjąć próbę rozwiązania tego problemu.

\section{Uwagi końcowe}

Przeprowadzone rozważania pozwalają na wstępną ocenę nowelizacji ustawy związkowej w zakresie dotyczącym art. $25^{1}$. Dokonując tej oceny w pierwszej kolejności z punktu widzenia legislacyjnej poprawności (zasady poprawnej legislacji zawarte są w rozporządzeniu Prezesa Rady Ministrów z dn. 20 czerwca 2002 r. w sprawie „Zasad techniki prawodawczej”, Dz.U. 2016, poz. 283 tekst jedn.), należy stwierdzić, że przez znaczne rozbudowanie przepisów art. $25^{1}$ omawiana regulacja stała się bardziej precyzyjna i wyczerpująca. Dotychczas wiele spraw dotyczących liczby członków jako kryterium posiadania przez organizację związkową uprawnień zakładowej organizacji związkowej pozostawało poza zakresem regulacji (np. konsekwencje zmian stanu liczbowego organizacji związkowej w okresie sprawozdawczym, skutki niewykonania przez organizację związkową obowiązku informacyjnego czy możliwość weryfikacji informacji przekazywanych przez organizację). Przyczyniało się to do powstawania sporów interpretacyjnych, które nie zawsze były rozwiązywane przez zgodne wypowiedzi doktryny i judykatury. Obecnie kwestie te znajdują wyraźne odzwierciedlenie w przepisach, co wzmacnia stan pewności prawnej. Można przypuszczać, że będzie to miało pozytywny wpływ na praktykę funkcjonowania organizacji związkowych. 
Oceniając $z$ kolei nowe przepisy art. $25^{1}$ u.z.z. z punktu widzenia kierunku przeprowadzonych zmian, należy zwrócić szczególną uwagę na rozszerzenie kręgu związkowców uwzględnianych przy ustalaniu, czy organizacjom związkowym przysługują uprawnienia zakładowej organizacji związkowej. Dzięki temu rozwiązaniu wskazane organizacje mogą łatwiej - przynajmniej teoretycznie - spełniać wymogi, od których zależy posiadanie przez nie uprawnień związkowych.

Wspomniane wymogi pozostają co do istoty bez zmian (zrzeszanie przez organizacje związkowe co najmniej 10 członków o określonym statusie). To wraz z utrzymaniem międzyzakładowych organizacji związkowych jako jedynej alternatywy dla zakładowych organizacji związkowych (pomimo wadliwości ich konstrukcji prawnej i niesprawdzenia się w praktyce) powoduje, że nadal nierozwiązany pozostaje problem nieobecności związków zawodowych u mikropracodawców ze wszystkimi tego negatywnymi konsekwencjami dla zatrudnionych. W tym kontekście nowelizacja ustawy związkowej w zakresie dotyczącym art. $25^{1}$ nie do końca zasługuje na pozytywną ocenę. Jest ona niewystarczająca i wymaga uzupełnienia o nową formułę działania związków zawodowych u najmniejszych pracodawców.

\section{Bibliografia}

Baran K.W. (2010) Zbiorowe prawo pracy: komentarz, Warszawa.

Baran K.W. (2018) O zakresie prawa koalicji w związkach zawodowych - uwagi de lege ferenda [w:] G. Goździewicz (red.), Umowa o pracę a umowa o zatrudnienie, Warszawa.

Dubowik A. (2003) Zakładowa organizacja związowa po nowelizacji ustawy o związkach zawodowych, „Praca i Zabezpieczenie Społeczne”, nr 9.

Dubowik A. (2006) Liczba członków zakładowej organizacji związkowej jako czynnik determinujący jej status, „Praca i Zabezpieczenie Społeczne”, nr 9.

Florek L. (2012) Zalety i wady działalności związków zawodowych na szczeblu zakładowym [w:] Z. Hajn (red.), Związkowe przedstawicielstwo pracowników zakładu pracy, Warszawa. Florek L. (2018) Zakres podmiotowy wolności związkowej [w:] J. Stelina, J. Szmit (red.), Zbiorowe prawo zatrudnienia, Warszawa.

Goździewicz G. (2013) Ogólna charakterystyka stosunków pracy u małych pracodawców [w:] G. Goździewicz (red.), Stosunki pracy u małych pracodawców, Warszawa.

Hajn Z. (2012) Związkowe przedstawicielstwo pracowników zakładu pracy w Polsce - ewolucja, stan obecny, przyszłość [w:] Z. Hajn (red.), Związkowe przedstawicielstwo pracowników zakładu pracy, Warszawa.

Latos-Miłkowska M. (2012) Międzyzakładowa organizacja związkowa [w:] Z. Hajn (red.), Związkowe przedstawicielstwo pracowników zakładu pracy, Warszawa.

Latos-Miłkowska M. (2013) Ochrona interesu pracodawcy, Warszawa.

Piątkowski J. (2014) Przedstawicielstwo związkowe jako podmiot zakładowego dialogu społecznego [w:] J. Stelina (red.), Zakładowy dialog społeczny, Warszawa.

Płażek S., Sobczyk A. (2013) Wątpliwości wokół interpretacji nowych przepisów ustawy o związkach zawodowych, „Praca i Zabezpieczenie Społeczne”, nr 8. 
Pudełko W. (2013), Obowiązek informacyjny zakładowej organizacji związkowej o liczbie członków - termin wykonania obowiązku - skutki uchybienia obowiązkowi informacyjnemu. Glosa do wyroku SN z dnia 6 października 2011 r., III PK 17/11, OSP, nr 5, poz. 53.

Raport o stanie sektora małych i średnich przedsiębiorstw w Polsce (2018), https://www.parp. gov.pl/component/publications/publication/raport-o-stanie-sektora-msp-w-polsce-2018 (dostęp: 28.03.2019).

Rutkowska B. (2016) The Monopoly of Trade Unions in the Shaping of the Terms and Conditions of Remuneration for Work and Resolving Collective Disputes from the Perspective of the Protection of Rights and Interests of Employees [w:] J. Carby-Hall, M. Rycak (eds.), Trade Unions and Non-union Employee Representation in Europe - The Current State of Play and Prospects for the Future, Warsaw.

Sanetra W. (2012) Spory zbiorowe jako przedmiot postępowania sądowego [w:] G. Goździewicz (red.), Aktualne problemy zbiorowego prawa pracy w Polsce i w Niemczech, Torun.

Stelina J. (2013) Zbiorowa ochrona pracowników u małych i średnich pracodawców [w:] G. Goździewicz (red.), Stosunki pracy u małych pracodawców, Warszawa.

Szmit J. (2013) Oczekiwania zmian ustawodawstwa pracy w zakresie statusu prawnego pracowników zatrudnionych przez małych pracodawców z perspektywy związów zawodowych [w:] G. Goździewicz (red.), Stosunki pracy u małych pracodawców, Warszawa.

Szmit J. (2018) Delegat związkowy - propozycja regulacji [w:] J. Stelina, J. Szmit (red.), Zbiorowe prawo zatrudnienia, Warszawa.

Świątkowski A.M. (2013) Domniemanie zaprzestania działalności związkowej, „Monitor Prawa Pracy”, nr 11.

Zieliński T. (2000) Pojęcie i przedmiot zbiorowego prawa pracy [w:] G. Goździewicz (red.), Zbiorowe prawo pracy w społecznej gospodarce rynkowej: praca zbiorowa, Toruń.

\section{Orzecznictwo}

Wyrok SA w Katowicach z 29 grudnia 2015 r., III APa 41/15, LEX nr 1997497.

Uchwała SN z 20 grudnia 2012 r., III PZP 7/12, LEX nr 1274988.

Wyrok SN z 6 października 2011 r., III PK 17/11, LEX nr 1227510.

Wyrok SN z 2 marca 2012 r., I PK 120/11, LEX nr 1271581.

Wyrok SN z 19 sierpnia 2015 r., II PK 208/14, LEX nr 1802577.

Wyrok SN z 20 czerwca 2017 r., I PK 198/16, LEX nr 2342186.

Wyrok TK z 28 września 2006 r., K 45/04, OTK-A 2006, nr 8, poz. 111. 
